\title{
Pengaruh Budaya Organisasi, Komitmen Dan Akuntabilitas Pada Kinerja Lembaga Perkreditan Desa
}

\author{
Lidya Ayu Amanda ${ }^{1}$ \\ I D.G. Dharma Suputra ${ }^{2}$ \\ ${ }^{1,2}$ Fakultas Ekonomi dan Bisnis Universitas Udayana (Unud), Bali, Indonesia \\ e-mail: lidyaayuamanda@gmail.com
}

\begin{abstract}
ABSTRAK
Penelitian ini dilakukan di Lembaga Perkreditan Desa (LPD) di Kota Denpasar. Jumlah sampel yang diambil sebanyak 70 orang responden. Penelitian ini menggunakan sampel jenuh. Pengumpulan data dilakukan melalui wawancara, observasi dan kuisioner. Teknik analisis data yang digunakan adalah regresi linear berganda. Berdasarkan hasil analisis dapat dikemukakan bahwa budaya organisasi secara langsung berpengaruh terhadap positif kinerja LPD di Kota Denpasar. Komitmen secara langsung berpengaruh positif terhadap kinerja LPD di Kota Denpasar. Akuntabilitas secara langsung berpengaruh positif teradap kinerja LPD di Kota Denpasar. Adanya penerapan budaya organisasi, komitmen dan akuntabilitas yang baik pada organisasi akan memicu kinerja yang baik dalam suatu organisasi. Peran pemimpin organisasi harus memotivasi dan memberikan arahan kepada karyawannya tujuannya untuk membangun budaya organisasi, komitmen dan akuntabilitas dalam setiap diri karyawan (individu) untuk mencapai target organisasi yang sesuai organisasi inginkan.
\end{abstract}

Kata Kunci: Budaya organisasi, komitmen, akuntabilitas dan kinerja

\section{ABSTRACT}

This research was conducted at the Village Credit Institution (LPD) in Denpasar City. The number of samples taken was 70 respondents. This study uses saturated samples. Data collection is done through interviews, observation and questionnaires. The data analysis technique used is multiple linear regression. Based on the results of the analysis it can be stated that organizational culture directly influences the positive performance of LPDs in Denpasar City. Direct commitment has a positive effect on LPD performance in Denpasar City. Accountability directly influences positively on LPD performance in Denpasar City. The application of organizational culture, commitment and good accountability to the organization will trigger good performance in an organization. The role of the leader of the organization must motivate and provide direction to its employees the goal is to build organizational culture, commitment and accountability in each employee (individual) to achieve the target organization that the organization wants. Keywords: Organizational culture, commitment, accountability and performance

\section{PENDAHULUAN}

Lembaga Perkreditan Desa (LPD) merupakan sebuah badan usaha yang dimiliki oleh desa adat atau desa pakraman yang bergerak dibidang simpan pinjam. Desa adat atau desa pakraman merupakan kesatuan masyarakat hukum adat bersifat 
kemasyarakatan dan keagamaan. Seiring berkembangnya waktu, LPD sangat membantu perkembangan ekonomi desa, khususnya pada LPD Daerah Kota Denpasar. Pada umumnya LPD tidak terlepas dari penerimaan dan pengeluaran kas. Disanalah peran LPD mengelola keuangan masyarakat desa dengan menghimpun dana dari program tabungan, simpanan deposito, dan pinjaman kredit masyarakat dan menyalurkannya ke masyarakat desa yang kekurangan dana.

Untuk mendukung keberadaan Lembaga Perkreditan Desa di Bali, maka sebagai payung hukumnya pemerintah Provinsi Bali mengeluarkan Peraturan Daerah (Perda) No. 2 tahun 1988 tentang pembentukan dan susunan keanggotaan majelis pertimbangan dan pembinaan kebudayaan propinsi daerah tingkat I Bali. Yang kemudian diganti dengan Perda No.8 tahun 2002 tentang Lembanga Perkreditan Desa (LPD). Karena kebutuhan untuk mengikuti perkembangan keadaan pada tahun 2012 pemerintah provinsi Bali mengeluarkan Perda No.4 tahun 2012 sebagai payung hukum bagi keberadaan Lembaga Perkreditan Desa. Walaupun peraturannya berubah namun esensi LPD tetap tidak berubah. LPD tetap merupakan lembaga keuangan mikro yang pemiliknya adalah komunitas adat dengan sistem ekonomi bebanjaran khas Bali (Suartana, 2009).

Rudjito (2003) menyatakan adapun fungsi lembaga keuangan mikro dalam menggerakan perekonomian agar dapat berjalan dengan optimal harus memenuhi 3 (tiga) kualifikasi, antara lain : memiliki jaringan kerja yang kuat, berfungsi sebagai payment gateway (lalu lintas transaksi pembayaran) berjalan dengan baik, dan memahami kebutuhan pemerintah Daerah dan bisnis masyarakat setempat. 
Kurniawan (2013) menyatakan budaya organisasi yang baik tentunya akan mempengaruhi kualitas pelayanan LPD yang baik pula. Budaya organisasi sangat berpengaruh terhadap perilaku para anggota organisasi, sehingga jika budaya organisasi suatu LPD baik, maka tidak mengherankan jika anggota organisasi adalah orang-orang yang baik dan berkualitas pula. Prasetyono (2007) menyatakan bahwa banyak karya berpendapat tentang peran kunci budaya organisasi untuk mencapai keunggulan organisasi. Budaya organisasi baik secara langsung maupun tidak langsung akan berpengaruh terhadap komitmen organisasi dan kinerja.Sebagai makluk sosial, karyawan tidak lepas dari berbagai nilai dan norma yang berlaku di dalam organisasi. Budaya organisasi dapat mempengaruhi cara karyawan dalam bertingkah laku, cara menggambarkan pekerjaan, dan cara bekerja dengan karyawan lain. Dalam setiap organisasi, budaya organisasi selalu diharapkan baik karena baik budaya organisasi akan berhubungan dengan berhasil tidaknya organisasi mencapai tujuannya. Budaya organisasi yang positif akan memacu organisasi kearah yang lebih baik. Sedangkan, budaya organisasi yang negatif akan memberikan dampak yang negatif bagi organisasi. Oleh sebab itu, apabila budaya organisasi baik maka kinerja yang akan dicapai pasti juga akan baik. Hal ini didukung oleh penelitian (Kurniawan, 2013) bahwa budaya organisasi berpengaruh positif terhadap kinerja organisasi.

Komitmen organisasi tercipta karena adanya tanggung jawab yang besar dari personil organisasi terhadap pekerjaan yang diberikan padanya. Oleh karena itu personil organisasi akan menimbulkan rasa ikut memiliki (sense of belonging) bagi pekerja dan organisasi. Herlin (2014) menyatakan jika seorang individu 
memiliki komitmen organisasi yang rendah akan memiliki perhatian yang rendah pula dan cenderung memenuhi kepentingan pribadi. Dapat disimpulkan bawah dengan adanya komitmen yang tinggi dalam diri individu maka semakin tinggi kepeduliannya terhadap organisasi sehingga individu tersebut akan terus berusaha akan menjadikan organisasinya kearah yang lebih baik.

Selain itu terkait dengan rerangka manajemen berbasis kinerja, setiap individu bertanggungjawab atas kinerja. Terdapat lima tanggung jawab utama yang harus dipenuhi oleh setiap individu dalam organisasi untuk menciptakan kinerja yang diinginkan yaitu: (1) memberikan komitmen terhadap pencapaian tujuan, (2) meminta umpan balik atas kinerja yang telah ia lakukan, (3) melakukan komunikasi secara terbuka dan teratur dengan managernya, (4) mendapatkan data kinerja dan membagi data itu kepada pihak lain, dan (5) menyiapkan diri untuk dievaluasi atas kinerja yang telah ia capai.

Kinerja juga berarti prestasi kerja, prestasi menyelenggarakan sesuatu. Dengan demikian kinerja organisasi merupakan suatu prestasi kerja dan proses penyelenggaraan tujuan organisasi yang ingin dicapai. Secara umum dapat juga dikatakan bahwa kinerja merupakan usaha untuk mencapai suatu prestasi oleh organisasi dalam periode tertentu.

Herlin (2014) menyatakan setiap kegiatan organisasi harus dapat diukur dan dinyatakan keterkaitannya dengan pencapaian arah organisasi di masa yang akan datang yang dinyatakan dengan visi dan misi organisasi. Berhasil atau tidaknya seluruh kegiatan organisasi akan dipengaruhi oleh kinerja para karyawan itu sendiri. 
Selain budaya organisasi dan kinerja, akuntabilitas juga penting bagi sebuah organisasi. Akuntabilitas itu sendiri adalah sebuah konsep etika yang dekat dengan administrasi suatu organisasi, yang mempunyai beberapa arti, hal ini yang sering digunakan secara sinonim dengan konsep-konsep seperti yang dapat dipertanggungjawabkan (responsibility), kemampuan memberikan jawaban (answerability), yang dapat dipersalahkan (blameworthiness) dan yang mempunyai ketidakbebasan (liability). Sebuah organisasi dikatakan akuntabel jika memiliki kemampuan untuk menjelaskan kondisi yang dialami termasuk didalamnya keputusan yang diambil dan sebagai aktivitas yang dilakukan. Istilah akuntabilitas dalam bidang ilmu akuntansi dipisahkan dengan istilah responsibilitas atau diartikan sebagai pertanggung jawaban. Media akuntabilitas yang memadai dapat berbentuk laporan yang dapat mengekspresikan pencapaian tujuan melalui pengelolaan sumber daya suatu organisasi. Pencapaian tujuan merupakan salah satu ukuran kinerja individu maupun unit organisasi. Tujuan tersebut dapat dilihat dari rencara strategi organisasi, rencana kinerja, dan program kinerja tahunan.

Selain faktor-faktor diatas yang mempengaruhi kinerja adalah tentang kinerja itu sendiri. Kinerja merupakan terjemahan dari performance yang berarti prestasi kerja, pelaksanaan kerja, pencapaian kerja (Pratama, 2012). Setiap kegiatan oraganisasi harus dapat diukur dan dinyatakan keterkaitannya dengan pencapaian arah organisasi di masa yang akan datang yang dinyatakan dengan visi dan misi organisasi. Berhasil atau tidaknya seluruh kegiatan organisasi akan dipengaruhi oleh kinerja para karyawan itu sendiri. Kinerja organisasi yang baik, 
akan dapat tercapai apabila didukung oleh faktor-faktor yang mempengaruhi kinerja organisasi tersebut

Berdasarkan latar belakang penelitian yang telah diuraikan, maka tujuan penelitian ini adalah untuk mendapatkan bukti empiris pengaruh budaya organisasi, komitmen organisasi dan akuntabilitas organisasi pada kinerja LPD di kota Denpasar. Berdasarkan pada tujuan penelitian, kajian-kajian teori relevan dan hasil-hasil penelitian sebelumnya, maka hubungan antar variabel yang dikutip pada penelitian terdahulu adalah sebagai berikut:

Budaya organisasi mengikat para karyawan yang bekerja di dalam untuk berperilaku sesuai dengan budaya organisasi yang ada. Apabila pengertian ini ditarik kedalam organisasi, maka seperangkat norma sudah menjadi budaya dalam organisasi sehingga karyawan harus bersikap sesuai dengan budaya yang ada tanpa terpaksa. Keberadaan budaya dalam organisasi dapat menjadi perekat dan pedoman bagi seluruh kebijakan perusahaan serta tuntutan operasional bagi aspekaspek lain dalam organisasi. Jika nilai budaya perusahaan sudah menjadi pedoman dalam pembuatan aturan organisasi. Hal tersebut berarti bila budaya organisasinya baik maka persepsi kinerja juga akan baik.

Budaya organisasi adalah sistem atau nilai-nilai yang diyakini oleh semua anggota organisasi dan yang telah dipelajari, diterapkan, serta dikembangkan secara berkesinambungan, berfungsi sebagai sistem perekat dan dapat dijadikan acuan perilaku dalam perusahaan untuk mencapai tujuan perusahaan yang telah ditetapkan, sehingga secara langsung ataupun tidak langsung memiliki pengaruh terhadap persepsi kinerja organisasi. Penelitian yang dilakukan oleh Primadana 
(2008), berkesimpulan bahwa budaya organisasi berpengaruh positif terhadap organisasi. Penelitian tersebut juga didukung oleh (Fajrina, 2009) yang menyimpulan bahwa budaya organisasi berpengaruh positif terhadap kinerja organisasi. Rumusan hipotesis antara budaya organisasi dengan kinerja organisasi: $\mathrm{H}_{1:}$ Semakin baik budaya suatu organisasi maka semakin baik kinerjanya

Konsep tantang komitmen organisasi berkembang pada studi awal mengenai loyalitas individu yang diharapkan ada pada diri karyawan. Keterikatan kerja yang sangat erat merupakan suatu kondisi yang dirasakan seorang karyawan, sehingga menimbulakan perilaku positif yang kuat terhadap organisasi kerja yang dimiliki. Menurut Porter et al., (1974) suatu bentuk ikatan kerja yang kuat bukan bersifat loyalitas yang pasif, tetapi juga melibatkan hubungan yang aktif dengan organisasi kerja yang dimiliki tujuan memberikan usaha demi keberhasilan pelaksanaan tujuan organisasi. Berarti karyawan yang memiliki komitmen yang tinggi akan melakukan segala usaha agar dapat mencapai tujuan organisasi. Apabila tujuan organisasi tercapai maka persepsi kinerja organisasi akan menjadi lebih baik.

Komitmen organisasi yang kuat akan mendorong individu untuk berusaha lebih keras dalam mencapai tujuan organisasi. Sehingga komitmen yang tinggi akan menjadikan individu lebih mementingkan organisasi dari pada kepentingan pribadi dan berusaha menjadikan organisasi menjadi lebih baik lagi. Komitmen organisasi yang tinggi akan meningkatkan persepsi kinerja yang tinggi pula. Penelitian yang dilakukan oleh Sri dkk., (2015), menyimpulkan bahwa komitmen oraganisasi mempunyai pengaruh yang positif terhadap kinerja pegawai. Hal ini 
juga didukung oleh penelitian yang dilakukan Ivano (2009) yang menyatakan bahwa komitmen organisasi berpengaruh positif terhadap kinerja. Rumusan hipotesis antara komitmen organisasi dengan kinerja organisasi:

$\mathrm{H}_{2}$ : Semakin komit sebuah organisasi semakin baik kinerja organisasinya

Kinerja organisasi publik dinilai dari bagaimana anggota-anggota dalam organisasi sektor publik untuk memberikan layanan yang terbaik dengan mendayagunakan sumberdaya yang ada di organisasinya untuk memberikan kepuasan kepada masyarakat sebagai pihak yang dilayani. Komitmen merupakan sebuah sikap dan perilaku yang mendorong antara satu dengan yang lain. Komitmen karyawan dengan organisasinya adalah kesetiaan karyawan terhadap organisasinya, disamping juga akan menumbuhkan loyalitas serta mendorong keterlibatan diri karyawan dalam mengambil berbagai keputusan. Oleh karenanya komitmen akan menimbulkan rasa ikut memiliki bagi karyawan terhadap organisasi.

Keberhasilan dalam perusahaan sangat tergantung pada keberhasilannya dalam menciptakai budaya organisasi yang khas sebagai bagian dari rencara strategik. Adanya keterkaitan hubungan antara budaya organisasi dan kinerja organisasi yang dijelaskan bahwa semakin baik kualitas faktor-faktor yang terdapat dalam budaya organisasi semakin baik kinerja organisasi tersebut. Didukung dengan sumber daya manusia yang ada sistem dan teknologi, strategi perusahaan dan logistik, masing-masih kinerja individu yang baik akan menimbulkan organisasi yang baik pula. 
Akuntabilitas publik adalah suatu yang menunjukan seberapa besar tingkat kesesuaian ukuran atau standar penyelenggaraan penyusunan kebijakan publik dengan peraturan hukum dan perundang-undangan yang berlaku untuk organisasi yang bersangkutan. Julia (2012) menyatakan bahwa akuntabilitas tidak berpengaruh terhadap kinerja. Sedangkan Lestari (2014) menyatakan bahwa akuntabilitas berpengaruh positif terhadap kinerja organisasi dengan mengunakan sistem akuntansi sederhana dalam pengelolaan keuangannya. Sedangkan Hwang (2013) menyatakan bahwa akuntabilitas berpengaruh positif terhadap kinerja.

$\mathrm{H}_{3}$ : Semakin akuntabel sebuah organisasi semakin baik kinerja organisasinya

\section{METODE PENELITIAN}

Desain penelitian yang digunakan penulis adalah desain asosiatif yang bertujuan untuk mengetahui hubungan antara dua variabel atau lebih. Desain dari penelitian ini seperti pada Gambar 1 berikut.

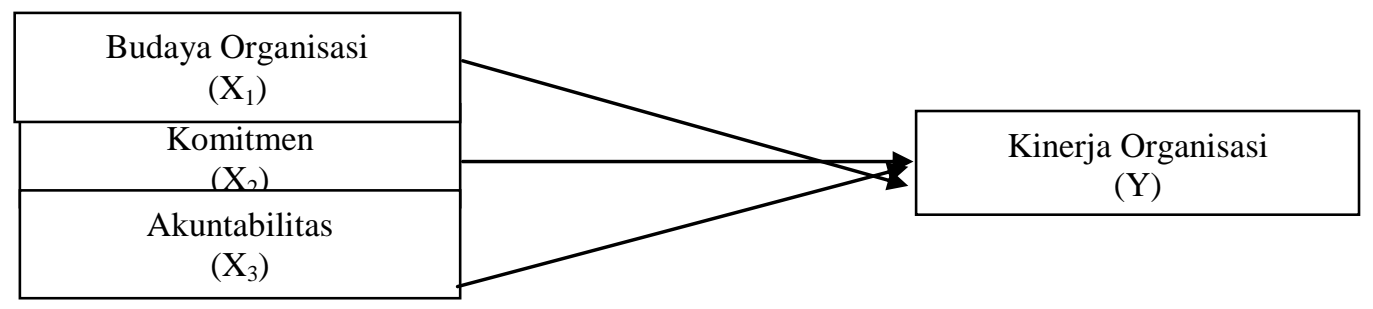

Sumber : Data diolah, 2018

Gambar 1. Desain Penelitian

Lokasi penelitian ini dilakukan pada LPD yang berada di Kota Madya Denpasar. Lokasi penelitian ini dilakukan pada Lembaga Pemberdayaan Lembaga Perkreditan Desa (LP LPD) Denpasar yang merupakan lembaga pemerintahan yang memberikan pembinaan dan pengawasan bagi LPD yang berada di 
kota/kabupaten di Bali. Pemilihan kota Denpasar untuk menjadi lokasi penelitian karena semakin berkembangnya kota Denpasar, maka perkembangan LPD semakin pesat dalam membantu masyarakat sekitar untuk melakukan kegiatan menyimpan dan meminjam dana. Objek penelitian ini adalah pengaruh budaya organisasi, komitmen, dan akuntabilitas pada persepsi kinerja Lembaga Perkreditan Desa (LPD) studi empiris pada LPD di kota Denpasar.

Variabel bebas dalam penelitian ini adalah Budaya Organisasi $\left(\mathrm{X}_{1}\right)$, Komitmen $\left(\mathrm{X}_{2}\right)$, Akuntabilitas $\left(\mathrm{X}_{3}\right)$. Sedangkan, Variabel terikat dalam penelitian ini adalah Kinerja Organisasi.

Data kuantitaf yang digunakan adalah jumlah karyawan dan jawabanjawaban kuisioner yang telah dikuantitatifkan oleh peneliti atas pertanyaanpertanyaan dalam kuisioner mengenai kinerja Lembaga Perkreditan Desa. Data kualitatif yang tercantum dalam penelitian ini antara lain: sejarah perusahaan, struktur organisasi, prosedur kinerja Lembaga Perkreditan Desa (LPD). Data primer dalam penelitian ini adalah hasil wawancara dan jawaban atas kuisioner yang diberikan kepada responden mengenai kinerja Lembaga Perkreditan Desa. Sedangkan Data skunder dalam penelitian ini adalah struktur organisasi, misi dan visi.

Populasi dalam penelitian ini adalah 35 Lembaga Perkreditan Desa di kota Denpasar. Penelitian ini menggunakan sampel jenuh. Jadi, seluruh LPD dilibatkan dalam penelitian ini responden dipilih berdasarkan kriteria tertentu sebagai berikut:

Tabel 1. 


\begin{tabular}{clc}
\hline No & \multicolumn{1}{c}{ Kriteria Responden } & Jumlah \\
\hline \multicolumn{2}{l}{ Jumlah karyawan LPD di Kota Denpasar } & 525 \\
1 & Karyawan yang bekerja minimal 5 tahun. & \\
2 & Bekerja sebagai karyawan bagian tabungan dan kredit. & \\
& $\quad$ Bagian tabungan & 35 \\
& $\quad$ Bagian kredit & 35 \\
& Jumlah responden yang memenuhi kriteria & 70
\end{tabular}
Sumber : Data diolah, 2019

Metode pengumpulan data yang digunakan adalah wawancara, observasi dan kuisioner. Jawaban responden terhadap pernyataan dalam kuisioner tersebut diukur dengan menggunakan skala Likert, yaitu pilihan jawaban responden diberi nilai dengan skala 5 poin. Selanjutnya jawaban responden yang sudah terkumpul direkapitulasi dan dilakukan pengujian instrumen. Uji instrumen dalam penelitian ini terdiri dari uji validitas dan uji reliabilitas. Pengujian ini dilakukan untuk mengetahui apakah instrumen dari data penelitian berupa jawaban dengan benar atau tidak. Apabila data sudah dinyatakan layak dan sudah lolos uji validitas dan reliabiltas, maka selanjutnya dilakukan uji asumsi klasik karena model regresi yang baik adalah model regresi yang terbebas dari masalah normalitas data, multikolinieritas, dan heteroskedastisitas.

Teknik analisis data yang digunakan dalam penelitian ini adalah regresi linear berganda digunakan untuk mengukur pengaruh antara lebih dari satu variabel bebas terhadap variabel terikat yaitu untuk mengetahui pengaruh sistem budaya organisasi, komitmen dan akuntabilitas pada kinerja lembaga perkreditan desa (LPD). Adapun bentuk persamaan regresi yang digunakan dalam penelitian ini adalah sebagai berikut:

$\mathrm{Y}=\alpha+\beta_{1} \mathrm{X}_{1}+\beta_{2} \mathrm{X}_{2}+\beta_{3} \mathrm{X}_{3}+\mathrm{e}$

Keterangan: 


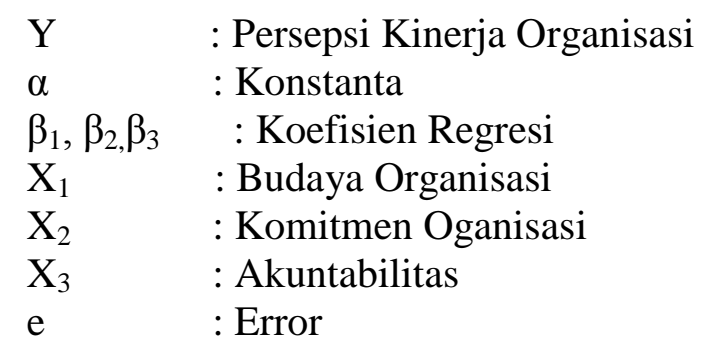

\section{HASIL DAN PEMBAHASAN}

Item-item pertanyaan pada kuisioner yang digunakan pada suatu penelitian harus valid. Untuk menentukan validitas item-item pada kuisioner, dilakukan uji validitas pada tiap item pertanyaan kuisioner. Statistik uji yang digunakan pada uji validitas adalah r-hitung. Nilai r-hitung akan dibandingkan dengan nilai r-tabel yang diperoleh dari tabel $\mathrm{r}$ (pearson product moment) dengan derajat bebas (degree of freedom/df) sebesar n-2 dimana $\mathrm{n}$ adalah jumlah responden yang digunakan. Pada penelitian ini jumlah responden yang digunakan adalah 70 sehingga derajat bebas pada tabel $\mathrm{r}$ adalah 68. Nilai $\mathrm{r}$-tabel untuk derajat bebas 68 adalah sebesar 0.235 . Nilai r-hitung item yang lebih besar dari 0.235 dinyatakan valid. Adapun hasil uji validitas dapat dilihat pada Tabel 2 berikut:

Tabel 2.

Hasil Uji Validitas

\begin{tabular}{lccccc}
\hline No. & Variabel Penelitian & & Nilai r hitung & Nilai r tabel & Keterangan \\
\hline \multirow{3}{*}{1} & Kinerja & Y.1 & 0.404 & 0.235 & Valid \\
& & Y.2 & 0.697 & 0.235 & Valid \\
& & Y.3 & 0.416 & 0.235 & Valid
\end{tabular}




\begin{tabular}{|c|c|c|c|c|c|}
\hline & & Y.4 & 0.533 & 0.235 & Valid \\
\hline & & Y.5 & 0.661 & 0.235 & Valid \\
\hline & & Y.6 & 0.698 & 0.235 & Valid \\
\hline & & Y.7 & 0.426 & 0.235 & Valid \\
\hline & & Y.8 & 0.507 & 0.235 & Valid \\
\hline & & Y.9 & 0.647 & 0.235 & Valid \\
\hline & & Y.10 & 0.701 & 0.235 & Valid \\
\hline & & $\mathrm{X} 1.1$ & 0.743 & 0.235 & Valid \\
\hline & & $\mathrm{X} 1.2$ & 0.421 & 0.235 & Valid \\
\hline & & $\mathrm{X} 1.3$ & 0.627 & 0.235 & Valid \\
\hline & & $\mathrm{X} 1.4$ & 0.667 & 0.235 & Valid \\
\hline 2 & Budaya Organisasi & $\mathrm{X} 1.5$ & 0.604 & 0.235 & Valid \\
\hline & & X1.6 & 0.709 & 0.235 & Valid \\
\hline & & $\mathrm{X} 1.7$ & 0.665 & 0.235 & Valid \\
\hline & & $\mathrm{X} 1.8$ & 0.743 & 0.235 & Valid \\
\hline & & X1.9 & 0.346 & 0.235 & Valid \\
\hline & & $\mathrm{X} 2.1$ & 0.647 & 0.235 & Valid \\
\hline & & $\mathrm{X} 2.2$ & 0.604 & 0.235 & Valid \\
\hline & & $\mathrm{X} 2.3$ & 0.545 & 0.235 & Valid \\
\hline & & $\mathrm{X} 2.4$ & 0.608 & 0.235 & Valid \\
\hline 3 & Komitmen Organisasi & $\mathrm{X} 2.5$ & 0.425 & 0.235 & Valid \\
\hline & & $\mathrm{X} 2.6$ & 0.433 & 0.235 & Valid \\
\hline & & $\mathrm{X} 2.7$ & 0.408 & 0.235 & Valid \\
\hline & & $\mathrm{X} 2.8$ & 0.638 & 0.235 & Valid \\
\hline & & X2.9 & 0.647 & 0.235 & Valid \\
\hline & & $\mathrm{X} 2.10$ & 0.604 & 0.235 & Valid \\
\hline & & $\mathrm{X} 3.1$ & 0.419 & 0.235 & Valid \\
\hline & & $\mathrm{X} 3.2$ & 0.520 & 0.235 & Valid \\
\hline & & X3.3 & 0.671 & 0.235 & Valid \\
\hline & & $\mathrm{X} 3.4$ & 0.484 & 0.235 & Valid \\
\hline 4 & Akuntabilitas & $\mathrm{X} 3.5$ & 0.473 & 0.235 & Valid \\
\hline & & X3.6 & 0.596 & 0.235 & Valid \\
\hline & & X3.7 & 0.669 & 0.235 & Valid \\
\hline & & X3.8 & 0.671 & 0.235 & Valid \\
\hline & & X3.9 & 0.484 & 0.235 & Valid \\
\hline
\end{tabular}

Sumber : Data diolah, 2019

Tabel 2 di atas menunjukkan bahwa setiap item pertanyaan dari masingmasing variabel pada kuisioner memiliki nilai r-hitung yang lebih besar dari pada 
r tabel sebesar 0.235 sehingga 38 pertanyaan dalam kuisioner yang digunakan dinyatakan valid.

Suatu pengukur dikatakan reliabel jika dapat dipercaya. Uji reabilitas dilakukan dengan metode internal consistency. Reliabilitas instrumen penelitian dalam penelitian ini diuji dengan menggunakan koefisien Cronbach's Alpha. Suatu variabel dikatakan reliabel jika nilai Cronbach's Alpha $>0.60$.

Tabel 3.

Hasil Uji Reliabilitas

\begin{tabular}{clccc}
\hline No. & Variabel Penelitian & $\begin{array}{c}\text { Cronbach's } \\
\text { Apha }\end{array}$ & $\begin{array}{c}\text { Syarat } \\
\text { Cronbach's } \\
\text { Apha }\end{array}$ & Keterangan \\
\hline 1 & Kinerja & 0.855 & 0.600 & Reliabel \\
2 & Budaya Organisasi & 0.873 & 0.600 & Reliabel \\
3 & Komitmen Organisasi & 0.852 & 0.600 & Reliabel \\
4 & Akuntabilitas & 0.782 & 0.600 & Reliabel \\
\hline
\end{tabular}
Sumber : Data diolah, 2019

Uji reliabilitas pada Tabel 3 menyajikan nilai Cronbach's Alpha masing masing variabel pada kuisioner. Nilai Cronbach's Alpha yang dihasilkan lebih besar dari 0.6 sehingga dapat disimpulkan bahwa kuisioner yang digunakan sudah reliabel. Jika kuisioner sudah dinyatakan valid dan reliabel, maka kuisioner dapat digunakan sebagai alat ukur dan analisia lebih lanjut.

Menurut Ghozali (2012) uji normalitas bertujuan untuk menguji apakah dalam model regresi, variabel pengganggu atau residual memiliki distribusi normal. Seperti diketahui bahwa uji t dan F mengasumsikan bahwa nilai residual mengikuti distribusi normal. Kalau asumsi ini dilanggar maka uji statistik menjadi tidak valid untuk jumlah sampel kecil. Dalam pengujian ini, uji normalitas yang digunakan yaitu uji statistik non-parametrik Kolmogrov-Smirnov. Adapun dasar uji K-S yaitu apabila angka signifikansi ( $\mathrm{sig})>0,05$, maka data berdistribusi 
normal. Sebaliknya, apabila angka signifikansi $(\mathrm{sig})<0,05$, maka data tidak berdistribusi normal.

Tabel 4.

Hasil Uji Normalitas

\begin{tabular}{llr}
\hline & & \multicolumn{2}{c}{$\begin{array}{c}\text { Unstandardized } \\
\text { Residual }\end{array}$} \\
\hline $\mathrm{N}$ & Mean & 70 \\
Normal Parameters & OE-7 & \\
& Std. & 2.19965800 \\
& Deviatio & .051 \\
Most Extreme Differences & $\mathrm{n}$ & .051 \\
& Absolute & -.048 \\
Kolmogorov-Smirnov Z & Positive & .426 \\
Asymp. Sig. (2-tailed) & Negative & $\mathbf{. 9 9 3}$ \\
\hline Sumber : Data diolah, 2019 & &
\end{tabular}

Hasil uji Kolmogorov-Smirnov menunjukkan bahwa nilai Asymp. Sig. (2tailed) sebesar 0.993. Nilai ini lebih besar dari signifikan 0.05 sehingga dapat disimpulkan bahwa data mengikuti sebaran normal. Jadi, asumsi normalitas pada regresi telah terpenuhi.

Menurut Ghozali (2012) uji heterokedastisitas bertujuan menguji apakah model regresi terjadi ketidaksamaan variance dari residual satu pengamatan ke pengamatan yang lain. Dikatakan heteroskedastisitas apabila varian dari residual suatu pengamatan kepengamatan lain berbeda dan dikatakan heterokedastisitas apabila varian dari residual suatu pengamatan ke pengamatan lainnya tetap. Model regresi yang baik yaitu bila tidak terjadi heterokedastisitas atau homokedastisitas. Jika signifikan $\mathrm{t}$ dari hasil meregresi nilai absolute residual terhadap variabel bebas lebih dari 0.05 maka model regresi tidak mengandung hoterokedastisitas.

Tabel 5.

Hasil Uji Heteroskedastisitas

\begin{tabular}{lcccc}
\hline Model & $\begin{array}{c}\text { Unstandardized } \\
\text { Coefficients }\end{array}$ & $\begin{array}{c}\text { Standardized } \\
\text { Coefficients }\end{array}$ & $\mathrm{t}$ & Sig. \\
\hline
\end{tabular}




\begin{tabular}{|c|c|c|c|c|c|c|}
\hline & & $\mathrm{B}$ & Std. Error & Beta & & \\
\hline & (Constant) & 4.246 & 2.463 & & 1.724 & .089 \\
\hline & Budaya Organisasi & .012 & .038 & .037 & .302 & .764 \\
\hline 1 & Komitmen Organisasi & .010 & .037 & .033 & .259 & .796 \\
\hline & Akuntabilitas & .029 & .115 & .026 & .255 & .799 \\
\hline
\end{tabular}

Sumber : Data diolah, 2019

Jika model tersebut diuji secara parsial maka Tabel diatas menunjukkan bahwa semua variabel bebas yang digunakan pada penelitian yaitu budaya organisasi, komitmen organisasi dan akuntabilitas memiliki nilai lebih besar dari 0.05 sehingga dapat disimpulkan bahwa tidak terjadi heterokedasitas.

Uji multikolonieritas bertujuan untuk menguji apakah dalam model regresi ditemukan adanya korelasi antar variabel bebas (independen). Menurut Ghozali (2012) model regresi yang baik seharusnya tidak terjadi korelasi diantara variabel independen. Jika variabel independen memiliki nilai tolerance lebih besar dari $10 \%$ dan memiliki nilai Variance Inflation Factor (VIF) kurang dari 10, maka model regresi tersebut bebas dari masalah multikolinieritas.

Tabel 6.

Hasil Uji Multikolinieritas

\begin{tabular}{|c|c|c|c|c|c|c|c|c|}
\hline \multirow{2}{*}{\multicolumn{2}{|c|}{ Model }} & \multicolumn{2}{|c|}{$\begin{array}{c}\text { Unstandardized } \\
\text { Coefficients }\end{array}$} & \multirow{2}{*}{$\begin{array}{c}\begin{array}{c}\text { Standardized } \\
\text { Coefficients }\end{array} \\
\text { Beta }\end{array}$} & \multirow[t]{2}{*}{$\mathrm{t}$} & \multirow[t]{2}{*}{ Sig. } & \multicolumn{2}{|c|}{$\begin{array}{c}\text { Collinearity } \\
\text { Statistics }\end{array}$} \\
\hline & & $\mathrm{B}$ & Std. Error & & & & Tolerance & VIF \\
\hline \multirow{4}{*}{1} & (Constant) & 3.444 & 4.400 & & .783 & .437 & & \\
\hline & Budaya Organisasi & .266 & .066 & .270 & 4.013 & .000 & .937 & 1.067 \\
\hline & Komitmen Organisasi & .220 & .160 & .215 & 2.375 & .016 & .885 & 1.130 \\
\hline & Akuntabilitas & .374 & .141 & .416 & 2.660 & .011 & .926 & 1.080 \\
\hline
\end{tabular}

Tabel 6 diatas menunjukkan bahwa untuk semua variabel independen yang digunakan memiliki nilai VIF yang dihasilkan kurang dari 10 dan nilai tolerance > 10\% sehingga dapat disimpulkan bahwa tidak terjadi korelasi ganda (multikolinieritas) antar variabel independen. Oleh karena itu asumsi multikolinieritas telah terpenuhi. 
Hasil analisis regresi linier berganda dalam penelitian ini dapat dilihat pada Tabel 7 sebagai berikut :

Tabel 7.

Hasil Uji Analisis Regresi Linier Berganda

\begin{tabular}{|c|c|c|c|c|c|c|}
\hline \multirow{2}{*}{\multicolumn{2}{|c|}{ Model }} & \multicolumn{2}{|c|}{$\begin{array}{c}\text { Unstandardized } \\
\text { Coefficients }\end{array}$} & \multirow{2}{*}{$\begin{array}{c}\begin{array}{c}\text { Standardized } \\
\text { Coefficients }\end{array} \\
\text { Beta } \\
\end{array}$} & \multirow[t]{2}{*}{$\mathrm{t}$} & \multirow[t]{2}{*}{ Sig. } \\
\hline & & $\mathrm{B}$ & Std. Error & & & \\
\hline \multirow{4}{*}{1} & (Constant) & 3.444 & 4.400 & & .783 & .437 \\
\hline & Budaya Organisasi & .266 & .066 & .270 & 4.013 & .000 \\
\hline & Komitmen Organisasi & .220 & .160 & .215 & 2.375 & .016 \\
\hline & Akuntabilitas & .374 & .141 & .416 & 2.660 & .011 \\
\hline
\end{tabular}

Sumber : Data diolah, 2019

Berdasarkan Tabel 7 tersebut diperoleh model regresi berganda yang terbentuk pada penelitian ini adalah sebagai berikut:

$$
\mathrm{Y}=3.444+0.266 \mathrm{X} 1+0.220 \mathrm{X} 2-0.374 \mathrm{X} 3
$$

Nilai koefisien variabel budaya organisasi bernilai positif sebesar 0.266 maka artinya apabila nilai budaya organisasi naik satu satuan maka kinerja akan naik sebesar 0.266. Lalu, nilai koefisien variabel komitmen organisasi bernilai positif sebesar 0.220 maka artinya apabila nilai komitmen organisasi naik satu satuan maka Kinerja akan naik sebesar 0.220. Kemudian, nilai koefisien variabel akuntabilitas bernilai positif sebesar 0.374 maka artinya apabila nilai akuntabilitas naik satu satuan maka kinerja akan naik sebesar 0.374 .

Koefisien Determinasi $\left(\mathrm{R}^{2}\right)$ bertujuan untuk mengetahui seberapa besar variabel independen mampu menjelaskan dan mempengaruhi variabel dependen. . Nilai koefisien determinasi adalah antara nol dan satu. Nilai $\mathrm{R}^{2}$ yang kecil berarti kemampuan variabel-variabel independen dalam menjelaskan variasi dependen terbatas. Nilai yang mendekati satu berarti variabel-variabel indepenen memberikan hampir semua informasi yang dibutuhkan untuk memprediksi variasi 
variabel dependen (Ghozali, 2012). Persamaan yang di gunakan dalam menghitung koefisien determinasi adalah $\mathrm{D}=\mathrm{R}^{2} \mathrm{X} 100 \%$ atau $\mathrm{D}=\operatorname{Adjs} \mathrm{R}^{2} \mathrm{X}$ 100\%. Adapun hasil uji koefisien determinasi dalam penelitian ini dapat dilihat pada Tabel 8.

Tabel 8. Hasil Uji Koefisien Determinasi

\begin{tabular}{lrrrrr}
\hline Model & R & R Square & Adjusted R Square & $\begin{array}{l}\text { Std. Error of } \\
\text { the Estimate }\end{array}$ & $\begin{array}{l}\text { Durbin- } \\
\text { Watson }\end{array}$ \\
\hline 1 & $.855^{\mathrm{a}}$ & .731 & .719 & 2.24909 & 1.728 \\
\hline Sumber $:$ Data diolah, 2019 & & & & &
\end{tabular}

Analisis regresi yang digunakan adalah analisis regresi berganda sehingga koefisien determinasi yang digunakan adalah Adjusted $\mathrm{R}$ square (koefisien determinasi terkoreksi). Nilai koefisien yang diperoleh adalah sebesar 0,719, sehingga nilai determinasinya menjadi $0.719 \times 100 \%=71.9 \%$. Hal ini mengindikasikan bahwa persepsi kinerja dijelaskan $71.9 \%$ oleh variabel budaya organisasi, komitmen organisasi dan akuntabilitas sisanya dijelaskan oleh variabel lain yang tidak dimasukkan ke dalam penelitian.

Uji statistik F bertujuan untuk mengetahui kelayakan model regresi linier berganda sebagai alat analisis yang menguji pengaruh variable independen terhadap variable dependen. Pengujian dilakukan dengan menggunakan significance level $0.05(\alpha=5 \%)$. Hasil uji kelayakan model (Uji F) dalam penelitian ini dapat dilihat pada Tabel 9 sebagai berikut.

Tabel 9.

Hasil Uji Kelayakan Model (Uji F)

\begin{tabular}{|c|c|c|c|c|c|}
\hline Model & Sum of Squares & $\mathrm{df}$ & Mean Square & $\mathrm{F}$ & Sig. \\
\hline $1 \quad$ Regression & 907.415 & 3 & 302.472 & 59.796 & $.000^{\mathrm{b}}$ \\
\hline
\end{tabular}




\begin{tabular}{lrrr}
\hline Residual & 333.856 & 66 & 5.058 \\
Total & 1241.271 & 69 & \\
\hline Sumber : Data diolah, 2019 & & &
\end{tabular}

Pada Tabel 9 tersebut dapat dilihat nilai signifikan sebesar 0.000 atau < 0.05 menunjukkan bahwa variabel independen yang digunakan yaitu variabel variabel budaya organisasi, komitmen organisasi dan akuntabilitas berpengaruh signifikan secara simultan.

Uji t digunakan untuk menguji secara parsial masing-masing variabel. Hasil uji t dapat dilihat pada table coefficients pada kolom sig (significance), jika probabilitas nilai $\mathrm{t}$ atau signifikansi $<0.05$, maka dapat dikatakan bahwa terdapat pengaruh Antara variabel bebas terhadap variabel terikat secara parsial.

Namun, jika probabilitas nilai $\mathrm{t}$ atau signifikansi $>0.05$, maka dapat dikatakan bahwa tidak terdapat pengaruh yang signifikan masing-masing variabel bebas terhadap variabel terikat.

Tabel 10.

Hasil Uji Hipotesis

\begin{tabular}{|c|c|c|c|c|c|c|}
\hline \multirow{2}{*}{\multicolumn{2}{|c|}{ Model }} & \multicolumn{2}{|c|}{$\begin{array}{l}\text { Unstandardized } \\
\text { Coefficients }\end{array}$} & \multirow{2}{*}{$\begin{array}{c}\begin{array}{c}\text { Standardized } \\
\text { Coefficients }\end{array} \\
\text { Beta }\end{array}$} & \multirow[t]{2}{*}{$\mathrm{t}$} & \multirow[t]{2}{*}{ Sig. } \\
\hline & & $\mathrm{B}$ & Std. Error & & & \\
\hline \multirow{4}{*}{1} & (Constant) & 3.444 & 4.400 & & .783 & .437 \\
\hline & Budaya Organisasi & .266 & .066 & .270 & 4.013 & .000 \\
\hline & Komitmen Organisasi & .220 & .160 & .215 & 2.375 & .016 \\
\hline & Akuntabilitas & .374 & .141 & .416 & 2.660 & .011 \\
\hline
\end{tabular}

Sumber : Data diolah, 2019

Pengaruh budaya organisasi terhadap kinerja yang diuji secara parsial dengan menggunakan uji t, diperoleh nilai sig. sebesar 0.000. Nilai sig. ini lebih kecil dari 0.05 sehingga dapat disimpulkan bahwa variabel budaya organisasi memiliki pengaruh signifikan terhadap kinerja.

Pengaruh komitmen organisasi terhadap kinerja yang diuji secara parsial dengan menggunakan uji t, diperoleh nilai sig. sebesar 0.016. Nilai sig. ini lebih 
kecil dari 0.05 sehingga dapat disimpulkan bahwa variabel Komitmen Organisasi memiliki pengaruh signifikan terhadap Kinerja.

Pengaruh akuntabilitas terhadap kinerja yang diuji secara parsial dengan menggunakan uji t, diperoleh nilai sig. sebesar 0.011. Nilai sig. ini lebih kecil dari 0.05 sehingga dapat disimpulkan bahwa variabel Akuntabilitas memiliki pengaruh signifikan terhadap Kinerja.

Jenis data yang digunakan dalam penelitian ini adalah data kuantitatif yang berupa hasil kuisioner, jumlah karyawan LPD di Kota Denpasar dan data kuantitatif yang berupa daftar nama LPD di Kota Denpasar. Sedangkan data yang digunakan dalam penelitian ini adalah data primer yang berupa jawaban responden terhadap pertanyaan kuisioner dan daftar skunder berupa daftar nama LPD di Kota Denpasar.

Populasi dalam penelitian ini adalah seluruh karyawan pada LPD di Kota Denpasar yang berjumlah 525 orang. Sampel dari penelitian ini adalah karyawan yang menduduki jabatan di LPD di Kota Denpasar. Kuisioner ini disebarkan ke 35 LPD di Kota Denpasar, dengan jumlah 70 kuisioner, masing-masing 2 kuisioner di setiap LPD, karena dengan menyebarkan 2 kuisioner disetiap LPD akan memudahkan proses analisis data dan memudahkan dalam mengontrol kuisioner yang disebarkan. Sehingga hal ini dapat menghemat waktu dan tenaga Berdasarkan analisis di atas, dapat diketahui bahwa secara parsial budaya organisasi berpengaruhsignifikan terhadap kinerja LPD di kota Denpasar dengan t hitung 4.013 dan signifikansi 0.000. Pengaruh signifikan ini dikarekan budaya organisasi termasuk dalam organization development yang terikat erat dalam 
program, struktur organisasi dan pada akhirnya menyentuh aktivitas SDM memiliki nilai budaya yang kuat, adaptif, dan sesuai dengan tujuan LPD. Hasil ini konsisten dengan penelitian yang dilakukan oleh Nystrom (1993) menunjukan adanya pengaruh yang signifikan antara budaya organisasi terhadap suatu kinerja.

Berdasarkan hasil analisis di atas, dapat diketahui bahwa secara parsial komitmen organisasi berpengaruh signifikan terhadap kinerja LPD di kota Denpasar dengan t hitung 2.375 dan signifikansi 0.016 . komitmen organisasi didefinisikan sebagai pengukur kekuatan karyawan yang berkaitan dengan tujuan dan nilai organisasi (McNeese-Smith, 1996). Komitmen ini dicontohkan sebagai fungsi kepercayaan dan kepatuhan terhadap organisasi.

Komitmen karyawan (individu) akan mendorong terciptanya komitmen organisasi. Porter et al., (1974) menyatakan bahwa komitmen organisasi dapat didefinisikan sebagai "relative strength of an individual's identification with and involvement in a particular organizational". Hal ini sesuai dengan penelitian dari Hackett et al., (2001) yang mengatakan bahwa individu yang memiliki komitmen organisasi yang merupakan affective commitment melaksakan perannya karena hasrat yang ingin dilakukan, hasrat ini berdasarkan identifikasinya pada organisasi dan keinginannya untuk membantu organisasi mencapai tujuan.

Berdasarkan hasil analisis di atas, dapat diketahui secara parsial akuntabilitas berpengaruh signifikan terhadap kinerja LPD di kota Denpasar dengan t hitung 2.660 dan signifikansi 0.011 .

Salah satu ciri akuntabilitas adalah mampu memberikan ruang bagi masyarakat untuk terlibat dalam proses pembangunan dan pemerintahan. Secara 
umum, setiap pengelolaan APBD selalu di kaitkan dengan akuntabilitas. Penelitian ini mendapat hasil bahwa akuntabilitas perbengaruh terhadap kinerja LPD di kota Denpasar. Hal ini menunjukan bahwa LPD di kota Denpasar sudah memperhatikan akuntabilitas terhadap masyarakat sehingga masyarakat mengetahui upaya apa yang telah dilakukan LPD dalam rangka meningkatkan kinerjanya. Selain itu, akuntabilitas pada LPD di kota Denpasar menjadi foktor utama dalam penciptaan kinerja dan laporan keuangan.

Hasil uji hipotesis menunjukan bahwa budaya organisasi, komitmen dan akuntabilitas secara simultan berpengaruh signifikan terhadap kinerja LPD di kota Denpasar. Oleh karena itu, dapat disimpulkan bahwa semakin tinggi nilai budaya organisasi, komitmen dan akuntabilitas maka akan menunggakat pula kinerja LPD di kota Denpasar. Hasil ini konsisten dengan penelitian Kotler \& Heskett (1999) yang menyatakan bahwa budaya organisasi mempunyai kekuatan yang penuh serta berpengaruh pada individu dan kinerjanya bahkan lingkungannya. Oleh karena itu, agar tercipta kinerja yang optimal dalam organisasi dibutuhkan perangkat dan system yang baik agar terbentuk budaya, komitmen dan akuntabilitas Lembaga Perkreditan Desa (LPD) di kota Denpasar.

Implikasi penelitian ini berhubungan dengan Pengaruh Budaya Organisasi, Komitmen dan Akuntabilitas pada Persepsi Kinerja Lembaga Perkreditan Desa (LPD). Berdasarkan hasil penelitian implikasi dari penelitian dapat diuraikan sebagai berikut: Berdasarkan kesimpulan yang telah diambil dari hasil penelitian ini bahwa persepsi kinerja mempunyai peran yang sangat penting dalam Lembaga Perkreditan Desa (LPD). Agar LPD berjalan dengan baik, semestinya persepsi 
kinerja harus didukung dengan adanya budaya organisasi, Komitmen dan akuntabilitas yang baik, keberhasilan pengelolaan organisasi sangatlah ditentukan oleh keberhasilan kinerja pemimpin dan karyawan dalam sebuah organisasi tersebut, jika pimpinan dapat memimpin, menjalankan dan memberikan contoh yang baik terhadap karyawannya maka akan mempengaruhi cara karyawan bekerja dan cara karyawan berperilaku. Dalam hal ini, pemimpin dan karyawan dalam suatu organisasi harus bekerja sama dengan baik untuk mewujudkan persepsi kinerja yang baik, maka budaya organisasi, komitmen dan akuntabilitas dalam suatu organisasi juga harus berjalan dengan baik.

\section{SIMPULAN}

Berdasarkan hasil penelitian yang diperoleh melalui pengujian statistik serta pembahasan yang telah diuraikan pada bab sebelumnya, maka dapat diambil kesimpulan bahwa Budaya Organisasi berpengaruh positif dan signifikan terhadap Kinerja Lembaga Perkreditan Desa di Kota Denpasar, Komitmen berpengaruh positif dan signifikan terhadap Kinerja Lembaga Perkreditan Desa di Kota Denpasar, dan Akuntabilitas berpengaruh positif dan signifikan terhadap Kinerja Lembaga Perkreditan Desa di Kota Denpasar.

Berdasarkan kesimpulan diatas maka disarankan bagi peneliti selanjutnya untuk dapat menggunakan variabel lain sebagai variabel pemoderasi seperti menggunakan motivasi, gaya kepemimpinan, dan disiplin kerja. Bagi peneliti berikutnya juga hendaknya meneliti budaya organisasi, komitmen dan akuntabilitas terhadap kinerja pada lokasi penelitian dan periode yang berbeda. 


\section{REFERENSI}

Fajrina, D. S. F. (2009). Analisis Pengaruh Kepemimpinan, Disiplin Kerja dan Budaya Organisasi Terhadap Kinerja Pegawai Badan Perencanaan Pembangunan Daerah Kota Magelang. Skripsi Universitas Diponegoro.

Ghozali, I. (2012). Aplikasi Analisis Mutivariat dengan Program SPSS. Semarang: Badan Penerbit Undip.

Hackett, R. D., Lapierre, L. M., \& Hausdorf, P. A. (2001). Understanding The Links Between Work Commitment Contructs. Journal of Vocational Behavior, 58, 392-413.

Herlin, A. (2014). Pengaruh Budaya Organisasi dan Akuntabilitas Publik Terhadap Kinerja Organisasi Pada Kantor Wilayah Direktoral Perbendaharaan Bengkulu. Skripsi Universitas Bengkulu.

Hwang, K. (2013). The Impac of Accountability and Accountability Management on Performance at the Street Level. Dissertation Submitted to the Faculty of the Virginia Polytechnic Institute and State University in Partial Fulfillment of the Requirements for the Degree of Doctor of Philosophy in Public Administration and Public Affairs.

Ivano, Y. (2009). Pengaruh Motivasi dan Komitmen Organisasi Terhadap Kinerja Pegawai (Studi Pada Kantor Pertahanan BPN Kota Semarang). Skripsi Universitas Diponegoro.

Julia, D. N. (2012). Analisis Kinerja Rumah Sakit Swasta Berdasarkan Budaya Organisasi, Komitmen dan Akuntabilitas Publik (Survei pada Rumah Sakit Kasih Ibu di Surakarta). Skripsi Universitas Muhammadiyah Surakarta.

Kotler, P. J., \& Heskett, J. (1999). Corporate Culture And Performance. Jakarta: PT Prehalindo.

Kurniawan, M. (2013). Pengaruh Komitmen, Budaya Organisasi, dan Kepuasan Kinerja Organisasi Publik (Studi Empiris Pada SKPD Pemerintah Kabupatan Kerinci). Skripsi Fakultas Ekonomi Universitas Negeri Padang.

Lestari, A. K. D. (2014). Membedah Akuntabilitas Praktik Pengelolaan Keuangan Desa Pakraman Kubutambahan, Kecamatan Kubutambahan, Kabupatan Buleleng, Provinsi Bali (Sebuah Studi Interpretif pada Organisasi Publik Non Pemerintahan). E-Jurnal Universitas Pendidikan Ganesha, 2(1).

McNeese-Smith, D. (1996). Increasing Employee Productivity, job Statisfaction 
and Organizational Commitment. Hospital \& Health Service Administration, 41 .

Porter, L. W., Steers, R. M., \& Boulian, P. (1974). Organizational Commitment, Job Statisfaction and Turnover among Psychiatric Tecniciants. Journal Applied Psychology, 59, 603-609.

Prasetyono. (2007). Analisis Kinerja Rumah Sakit Daerah Dengan Pendekatan Balanced Scorecard Berdasarkan Komitmen Organisasi, Pengendalian Intern Dan Penerapan Prinsip-Prinsip Good Corporate Governance (GCG). Simposium Nasional Akuntansi IAI Makassar.

Pratama, Y. (2012). Pengaruh Budaya Oraganisasi Terhadap Kinerja Pegawai Pada Kantor Kecamatan Nanggung Kabupaten Bogor. Skripsi Universitas Indonesia.

Rudjito. (2003). Peran Lembaga Keuangan Mikro Dalam Otonomi Daerah Guna Menggerakan Ekonomi Rakyat Dan Menanggulangi Kemiskinan (Studi Kasus: Bank Rakyat Indonesia). Jurnal Ekonomi Rakyat.

Sri, W., Pradana, A., \& Adi, Y. (2015). Pengaruh Komitmen Organisasi, Budaya Organisasi, Dan Akuntabilitas Publik Terhadap Kinerja Organisasi Publik Pada Rumah Sakit Umum Daerah Kabupaten Buleleng. Jurnal Akuntansi Universitas Pendidikan Ganesha, 3(1).

Suartana, I. W. (2009). Aristektur Pengelolaan Risiko Pada Lembaga Perkreditan Desa (LPD). Bali: Udayana University Press. 